\title{
EMERGENCE, GROWTH, AND PRODUCTION OF COLORED COTTON SUBJECTED TO SALT STRESS AND ORGANIC FERTILIZATION ${ }^{1}$
}

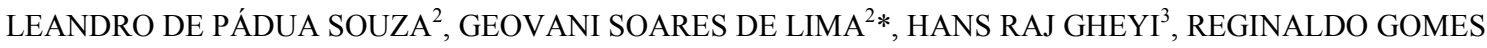 \\ NOBRE $^{4}$, LAURIANE ALMEIDA DOS ANJOS SOARES ${ }^{2}$
}

\begin{abstract}
The semi-arid region of Northeast Brazil is vulnerable to problems of water scarcity and salinity, resulting in low-quality irrigation water and the need to adopt cultivation strategies that make the production system viable. Given the above, this study aimed to evaluate emergence, growth, and production of colored cotton subjected to increasing levels of irrigation water salinity and organic matter doses. The experiment was carried out in an eutrophic Regolithic Neosol with a sandy loam texture in a greenhouse in the municipality of Campina Grande - PB, Brazil. A randomized block design was used in a 4 x 4 factorial scheme with three replicates, and the treatments corresponded to four levels of electrical conductivity of water $-\mathrm{ECW}$ $\left(1.7,3.4,5.1\right.$, and $\left.6.8 \mathrm{dS} \mathrm{m}^{-1}\right)$ and four doses of organic matter - OM $(0,2.5,3.5$, and 4.5\% based on soil volume). Increasing irrigation water salinity with $\mathrm{ECW}$ values above $1.7 \mathrm{dS} \mathrm{m}^{-1}$ reduced emergence, growth, and production of colored cotton, and the cotton seed weight was the variable most affected by salinity. Organic matter addition led to increased cotton growth and production, especially in terms of seed weight. Increasing doses of organic matter attenuated the effect of irrigation water salinity on the number of bolls in 'BRS Jady' cotton.
\end{abstract}

Keywords: Gossypium hirsutum L.. Salinity. Bovine manure.

\section{EMERGÊNCIA, CRESCIMENTO E PRODUÇÃO DO ALGODOEIRO COLORIDO SUBMETIDO AO ESTRESSE SALINO E ADUBAÇÃO ORGÂNICA}

RESUMO - A região semiárida do Nordeste Brasileiro é vulnerável aos problemas de escassez hídrica e salinidade, o que faz com que a maioria das águas utilizadas para irrigação nem sempre apresente boa qualidade, sendo necessária a adoção de estratégias de cultivo que viabilizem o sistema de produção. Diante do exposto, objetivou-se avaliar a emergência, o crescimento e a produção do algodoeiro de fibra colorida submetido a níveis crescentes de salinidade da água de irrigação e doses de matéria orgânica. O experimento foi conduzido em um Neossolo Regolítico Eutrófico de textura franco-arenosa em casa de vegetação no município de Campina Grande - PB. Utilizaram-se o delineamento experimental de blocos casualizados, em esquema fatorial $4 \times 4$, com três repetições, sendo os tratamentos compostos de quatro níveis de condutividade elétrica da água - $\mathrm{CEa}\left(1,7 ; 3,4 ; 5,1\right.$ e $\left.6,8 \mathrm{dS} \mathrm{m}^{-1}\right)$ e quatro doses de matéria orgânica - MO $(0 ; 2,5 ; 3,5$ e 4,5\% em base do volume de solo).O aumento da salinidade da água de irrigação com CEa superior a $1,7 \mathrm{dS} \mathrm{m}^{-1}$ reduziu a emergência, o crescimento e a produção do algodoeiro colorido, sendo a massa de algodão em caroço a variável mais afetada. A adição de matéria orgânica promoveu acréscimos no crescimento e produção do algodoeiro, especialmente na massa de algodão em caroço. Doses crescentes de matéria orgânica atenuaram o efeito da salinidade da água de irrigação sobre o número de capulhos do algodoeiro 'BRS Jady'.

Palavras-chaves: Gossypium hirsutum L.. Salinidade. Esterco bovino.

\footnotetext{
*Corresponding author

${ }^{1}$ Received for publication in $03 / 26 / 2017$; accepted in $10 / 23 / 2017$.

Paper extracted from the postdoctoral research of the second author.

${ }^{2}$ Center of Technology and Natural Resources, Universidade Federal de Campina Grande, Campina Grande, PB, Brazil; engenheiropadua@hotmail.com - ORCID: 0000-0001-7588-2413, geovanisoareslima@gmail.com - ORCID: 0000-0001-9960-1858, laurispo.agronomia@gmail.com - ORCID: 0000-0002-7689-9628.

${ }^{3}$ Nucleus of Soil and Water Engineering, Universidade Federal do Recôncavo da Bahia, Cruz das Almas, BA, Brazil; hans@pq.cnpq.br ORCID: 0000-0002-1066-0315.

${ }^{4}$ Center of Agrifood Science and Technology, Universidade Federal de Campina Grande, Pombal, PB, Brazil; rgomesnobre@yahoo.com.br - ORCID: 0000-0002-6429-1527.
} 


\section{INTRODUCTION}

Colored cotton cultivation has aroused the interest of producers and consumers in Brazil and worldwide and has become an expanding market with a great socioeconomic potential to generate jobs and provide raw material for the textile industry (DANIEL et al., 2011; SILVA et al., 2014). Cotton with naturally colored fiber also has a great environmental importance in terms of eliminating the dyeing stage in the industry (CARDOSO et al., 2010).

Despite being common in the northeastern region of the country, this crop has the lowest yields in this area, where the shortage of good-quality water has become a fundamental problem for the development of agriculture. Water sources with high concentrations of salts, especially sodium, are common (NEVES et al., 2009; JIANG et al., 2012).

When in excess, salts can cause osmotic stress in plants, reducing water availability, resulting in stomatal closure and, consequently, reduced carbon dioxide availability, potentially damaging the photosynthetic apparatus (ALVES et al., 2011; SÁ et al., 2015). This may induce ionic toxicity, leading to membrane disorganization, the production or reactive oxygen species, and nutritional imbalance (AREF; RAD, 2012; MGUIS et al., 2012).

Organic fertilization is essential for crop development in low-fertility soils, especially in a commercial production, due to the need to improve the product's quality and to meet the consumers' demands (ABREU et al., 2005); in addition, it mitigates the deleterious effects of salts on plants due to the positive impacts on physical characteristics of soil and the plant root environment. Humic substances released by the decomposition of organic sources stimulate the absorption of water and nutrients by plants in saline environments (MAHMOUD; MOHAMED, 2008; ASIK et al., 2009).

Studies conducted with other crops, such as sweet passion fruit (DAMATTO JÚNIOR; LEONEL; PEDROSO, 2005), watermelon (CAVALCANTE et al., 2010), sugar apple (CAVALCANTE et al., 2012), guava Oliveira et al. (2014), melon (RIBEIRO et al., 2014), and cashew (MELO FILHO et al., 2015), have already reported the beneficial effects of the application of organic fertilizers on plant growth and development. It is therefore crucial to conduct further studies that provide information on the adequate organic matter content to meet the nutritional requirements of the cotton crop under semi-arid conditions in Northeast Brazil.
In this context, this study aimed to evaluate the emergence, growth, and production of the colored fiber cotton cv. BRS Jady, subjected to irrigation with increasing levels of water salinity and to different doses of organic matter amendment.

\section{MATERIAL AND METHODS}

The experiment was carried out from October 2016 to January 2017 in a greenhouse at the Center of Sciences, Technology and Natural Resources (CTRN) of the Federal University of Campina Grande (UFCG), located in the municipality of Campina Grande, Paraíba, Brazil, at the geographic coordinates $7^{\circ} 15^{\prime} 18^{\prime}, \mathrm{S}, 35^{\circ} 52^{\prime} 28^{\prime}, \mathrm{W}$ and $550 \mathrm{~m}$ above sea level.

The experimental design consisted of randomized blocks in a $4 \times 4$ factorial scheme, corresponding to four levels of irrigation water salinity - ECW $\left(1.7,3.4,5.1\right.$, and $\left.6.8 \mathrm{dS} \mathrm{m}^{-1}\right)$ and four doses of organic matter - OM $(0,2.5,3.5$, and $4.5 \%$ based on soil volume). Combined, the factors resulted in 16 treatments, with 3 replicates and 1 plant per plot, totaling 48 plants.

The plants were grown in $20-\mathrm{L}$ plastic pots, which were perforated at the bottom and connected by drains to containers to collect drained water, allowing to monitor the drained volume and the crop water consumption. During the filling, the pots received a $250-\mathrm{g}$ layer of crushed stones, covering the bottom of the lysimeter, and $22 \mathrm{~kg}$ of a non-saline, non-sodic, eutrophic Regolithic Neosol with sandy loam texture, obtained from the municipality of Esperança, Paraíba, from the 0-30 cm layer (A horizon); the chemical and physical-hydraulic characteristics of the soil are presented in Table 1.

The different levels of bovine manure were aged and applied as basal fertilization; the amounts were determined considering the organic matter content in the manure as equal to $45 \%$. Top-dressing fertilization was performed using a formulation based on nitrogen $(\mathrm{N})$, phosphorus $(\mathrm{P})$, and potassium $(\mathrm{K})$, according to the recommendation for pot experiments by Novais, Neves and Barros (1991), applying 100,300 , and $150 \mathrm{mg} \mathrm{kg}^{-1}$ of soil of $\mathrm{N}, \mathrm{P}_{2} \mathrm{O}_{5}$, and $\mathrm{K}_{2} \mathrm{O}$, respectively, in the form of urea, monoammonium phosphate, and potassium chloride. Fertilization was split into two top-dressing applications and applied via the irrigation water at 22 and 38 days after sowing (DAS). The pots were arranged in single rows with a spacing of $1 \mathrm{~m}$ and $0.6 \mathrm{~m}$ between the plants in the row. 
Table 1. Chemical and physical characteristics of the eutrophic Regolithic Neosol used in the experiment, before applying the treatments.

\begin{tabular}{|c|c|c|c|c|c|c|c|c|}
\hline \multicolumn{9}{|c|}{ Chemical characteristics } \\
\hline \multirow[t]{2}{*}{$\mathrm{pH}_{\mathrm{ps}}$} & \multirow{2}{*}{$\begin{array}{c}\text { O.M } \\
\left(\text { dag kg }^{-1}\right)\end{array}$} & \multirow{2}{*}{$\begin{array}{c}\mathrm{P} \\
\left(\mathrm{mg} \mathrm{kg}^{-1}\right)\end{array}$} & $\mathrm{K}^{+}$ & $\mathrm{Na}^{+}$ & $\mathrm{Ca}^{2+}$ & $\mathrm{Mg}^{2+}$ & $\mathrm{Al}^{3+}$ & $\mathrm{H}^{+}$ \\
\hline & & & \multicolumn{6}{|c|}{ 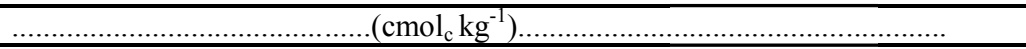 } \\
\hline 5.63 & 1.83 & 18.2 & 0.21 & 0.17 & 3.49 & 2.99 & 0.00 & 5.81 \\
\hline \multicolumn{9}{|c|}{ Physical characteristics } \\
\hline \multicolumn{3}{|c|}{ Size fraction $\left(\mathrm{g} \mathrm{kg}^{-1}\right)$} & \multirow{2}{*}{$\begin{array}{l}\text { Textural } \\
\text { class }\end{array}$} & \multicolumn{2}{|c|}{ Water content $(\mathrm{kPa})$} & \multirow[t]{2}{*}{ AW } & \multirow{2}{*}{$\begin{array}{c}\text { Total } \\
\text { porosity } \\
\mathrm{m}^{3} \mathrm{~m}^{-3}\end{array}$} & \multirow{2}{*}{$\begin{array}{c}\text { Density } \\
\left(\mathrm{kg} \mathrm{dm}^{-3}\right)\end{array}$} \\
\hline Sand & Silt & Clay & & 33.42 & $\begin{array}{c}1519.5 \\
\text { dag kg }^{-1}\end{array}$ & & & \\
\hline 572.3 & 100.8 & 326.9 & SL & 12.68 & 4.98 & 7.70 & 0.57 & 1.31 \\
\hline
\end{tabular}

O.M. - Organic matter: Walkley-Black wet digestion; $\mathrm{Ca}^{2+}$ and $\mathrm{Mg}^{2+}$ extracted with $1 \mathrm{~mol} \mathrm{~L}^{-1} \mathrm{KCl}$ at $\mathrm{pH} 7.0$; $\mathrm{Na}^{+}$and $\mathrm{K}^{+}$ extracted with $1 \mathrm{~mol} \mathrm{~L}^{-1} \mathrm{NH}_{4} \mathrm{OAc}$ at $\mathrm{pH}$ 7.0; ECse - Electrical conductivity of the saturation extract; SL - Sandy loam; AW - Available water.

Different saline solutions were prepared using the empirical relationship between the concentration of salts and the EC, as suggested by Richards (1954)

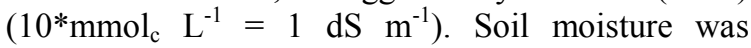
brought to a level corresponding to field capacity using water of the different salinity levels; subsequently, sowing was performed by planting eight seeds in each lysimeter equidistantly at a depth of $1.5 \mathrm{~cm}$. The first thinning was performed at 20 DAS, leaving only the five most vigorous plants per pot. Thinning was performed again at 26 and 30 DAS, eliminating two plants from each pot.

The plants were irrigated daily; each lysimeter received a water volume necessary to maintain the field capacity of the soil. The volume applied in each irrigation event was determined according to the plant water requirement, estimated by water balance: applied water volume minus volume drained in the previous irrigation plus a leaching fraction of 0.10 .

As phytosanitary control, plants were sprayed with the insecticide dimethoate at a concentration of $1.5 \mathrm{~mL} \mathrm{~L}^{-1}$ to control white fly, as recommended by the manufacturer. Plants were sprayed always at 05:00 p.m. to minimize negative impacts on insect pollinators.

The effects of the different treatments were evaluated in the period between emergence and production of the cotton cv. BRS Jady, based on the variables emergence speed index (ESI), plant height $(\mathrm{PH} ; \mathrm{cm})$, stem diameter $(\mathrm{SD} ; \mathrm{mm})$, and leaf area $\left(\mathrm{LA} ; \mathrm{cm}^{2}\right)$ at 40 and 60 DAS. The number of days to flower bud opening (NDFBO) and the flower abortion rate (FAR) were determined at $80 \mathrm{DAS}$, while the total number of bolls (TNB) and seed cotton weight (SCW) were determined at 114 DAS.

Cotton emergence was assessed by daily recording, until 7 DAS, the number of emerged plants, adopting as criterion the appearance of the epicotyl on the soil surface, which allowed the determination of emergence percentage - $\mathrm{E} \%$ (number of emerged seedlings in relation to the number of seeds sown). Emergence speed index (ESI) was estimated at 7 DAS, using the methodology described by Vieira and Carvalho (1994), according to Eq.1:

$$
\text { ESI (seedlings day } \left.{ }^{-1}\right)=\frac{\sum_{1}}{\mathrm{~N}_{1}}+\frac{\sum_{2}}{\mathrm{~N}_{2}} \ldots+\frac{\sum_{\mathrm{n}}}{\sum_{\mathrm{n}}}
$$

Where $\Sigma_{1}, \Sigma_{2}, \ldots \Sigma_{\mathrm{n}}$ represent the number of emerged seedlings, at first, second, and last counts, while $\mathrm{N}_{1}, \mathrm{~N}_{2}, \ldots \mathrm{N}_{\mathrm{n}}$ are the number of days from sowing to the first, second, and last counts, respectively.

The PH was determined by measuring the distance between root flare and the youngest leaf insertion point; SD was determined using a digital caliper $5 \mathrm{~cm}$ above the soil level. In the LA estimation, measurements of the midrib length of each leaf $(\mathrm{cm})$ were taken, considering only leaves with a minimum length of $1.5 \mathrm{~cm}$ and a photosynthetically active area of at least $50 \%$. Total leaf area was obtained according to the methodology described by Grimes and Carter (1969), using Eq.2:

$$
\mathrm{Y}=\sum 0.4322 \mathrm{x}^{2.3002}
$$

where: $\mathrm{Y}=$ leaf area per leaf, $\mathrm{cm}^{2} ; \mathrm{x}=$ midrib length of cotton leaves, $\mathrm{cm}$.

The variable NDFBO was estimated by daily monitoring flower bud opening, whereas the flower abortion rate was determined based on the relationship between the number of open flower buds and the total number of bolls, in percentage. Bolls were harvested per plant, as they reached the harvesting point, and seed cotton weight was determined by weighing on a precision scale $(0.001$ g accuracy).

Data were subjected to analysis of variance (ANOVA), using the $\mathrm{F}$ test. In cases of significance, 
linear and quadratic polynomial regression analyses were applied, using the statistical software SISVAR version 5.3 (FERREIRA, 2011).

\section{RESULTS AND DISCUSSION}

According to the results of the ANOVA (Table 2), irrigation water salinity and organic matter doses had significant effects on emergence speed index, stem diameter, plant height, and leaf area, in all studied periods. The interaction between water salinity and organic matter doses had an effect only on stem diameter at 60 DAS.

Table 2. Summary of analysis of variance for emergence speed index (ESI), stem diameter (SD), plant height (PH) and leaf area (LA) at 40 and 60 days after sowing in the cotton cv. BRS Jady irrigated with saline water and under different doses of organic matter.

\begin{tabular}{|c|c|c|c|c|c|c|c|c|}
\hline \multirow{3}{*}{ Source of variation } & \multirow{3}{*}{ DF } & \multicolumn{7}{|c|}{ Mean squares } \\
\hline & & ESI & \multicolumn{2}{|c|}{ SD } & \multicolumn{2}{|c|}{$\begin{array}{l}\text { PH } \\
\text { ays after sowing }\end{array}$} & \multicolumn{2}{|c|}{ LA } \\
\hline & & & 40 & 60 & 40 & 60 & 40 & 60 \\
\hline Saline levels (SL) & 3 & $0.12 * *$ & $0.33 * *$ & $2.60 * *$ & $112.94 * *$ & $507.96 * *$ & $6366.26^{*}$ & $671561.75^{* *}$ \\
\hline Linear regression & 1 & $0.11 * *$ & $0.92 * *$ & $7.42 * *$ & $328.77 * *$ & $1520.06 * *$ & $184732.31 * *$ & $194289.88^{* *}$ \\
\hline Quadratic regression & 1 & $0.23 * *$ & $0.04^{\mathrm{ns}}$ & $0.0001^{\mathrm{ns}}$ & $9.10^{\mathrm{ns}}$ & $2.16^{\mathrm{ns}}$ & $6093.68^{\mathrm{ns}}$ & $78294.00^{\mathrm{ns}}$ \\
\hline Organic matter (OM) & 3 & $0.16^{* *}$ & $14.32 * *$ & $13.14 * *$ & $1050.87 * *$ & $1681.02 * *$ & $390369.12 * *$ & $1426656.81^{* *}$ \\
\hline Linear regression & 1 & $0.04 * *$ & $32.43 * *$ & $25.64 * *$ & $1735.05 * *$ & $3343.57 * *$ & $948412.82 * *$ & $3763409.46^{* *}$ \\
\hline Quadratic regression & 1 & $0.23 * *$ & $9.69^{* *}$ & $11.54 * *$ & $1364.26^{* *}$ & $1536.80 * *$ & $190329.34 * *$ & $513536.15^{*}$ \\
\hline Interaction (SL x OM) & 9 & $0.15^{\text {ns }}$ & $0.25^{\mathrm{ns}}$ & $0.37 * *$ & $17.83^{\mathrm{ns}}$ & $30.46^{\mathrm{ns}}$ & $13578.14^{\mathrm{ns}}$ & $77856.94^{\mathrm{ns}}$ \\
\hline Blocks & 2 & $0.01^{\mathrm{ns}}$ & $0.06^{\mathrm{ns}}$ & $0.02^{\mathrm{ns}}$ & $54.88^{*}$ & $99.44 *$ & $11452.35^{\text {ns }}$ & $69149.16^{\mathrm{ns}}$ \\
\hline Residual & & 5.44 & 5.75 & 4.67 & 10.06 & 9.79 & 33.56 & 32.11 \\
\hline
\end{tabular}

$\mathrm{ns}, * *$, *espectively, not significant, significant at $\mathrm{p}<0.01$ and $\mathrm{p}<0.05$.

The increment in irrigation water electrical conductivity led to a reduction in ESI and, according to the regression equations (Figure 1A), there was a linear effect with the reduction of $0.37 \%$ per unit increase; i.e., plants irrigated at the highest salinity level $\left(6.8 \mathrm{dS} \mathrm{m}^{-1}\right)$ showed losses of $1.92 \%$ compared with those under ECw of $1.7 \mathrm{dS} \mathrm{m}^{-1}$. The reduction in ESI caused by the increment in the concentration of soluble salts in the soil occurs due to the decrease in water absorption capacity, which has a direct influence on processes such as cell division and differentiation, enzymatic activity, and nutrient uptake and distribution, possibly leading to a delay in seedling emergence and the mobilization of reserves or even a decrease in seed viability (VOIGT et al., 2009). Lopes and Silva (2010), studying the effects of different saline concentrations $(0,2,4,6$,

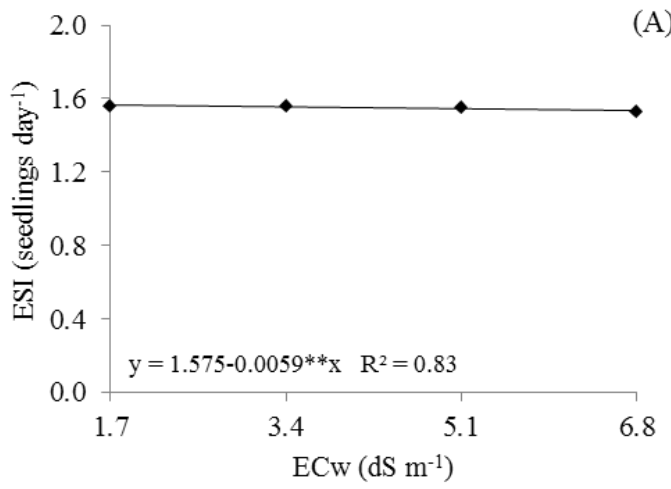

and $8 \mathrm{~g} \mathrm{~L}^{-1}$ ) on the germination of the cotton cv. BRS Rubi, reported a linear reduction in ESI, which reached values lower than $64.45 \%$ at concentrations higher than $4 \mathrm{~g}$ of $\mathrm{NaCl} \mathrm{L}-1\left(7.5 \mathrm{mS} \mathrm{cm}^{-1}\right)$ in the irrigation solution.

According to Figure 1B, the emergence speed index fitted best to a quadratic regression model, as $\mathrm{OM}$ increased and its highest value, corresponding to 1.64 seedling day ${ }^{-1}$, was obtained in plants fertilized with an OM dose of $1.7 \%$. According to Clemente et al. (2012), ESI is influenced by the increase in soil organic matter, which leads to an increment in cation exchange capacity, contributing to the improvement of structure and, consequently, resulting in higher water infiltration and retention and increased aeration and soil microbial activity and diversity.

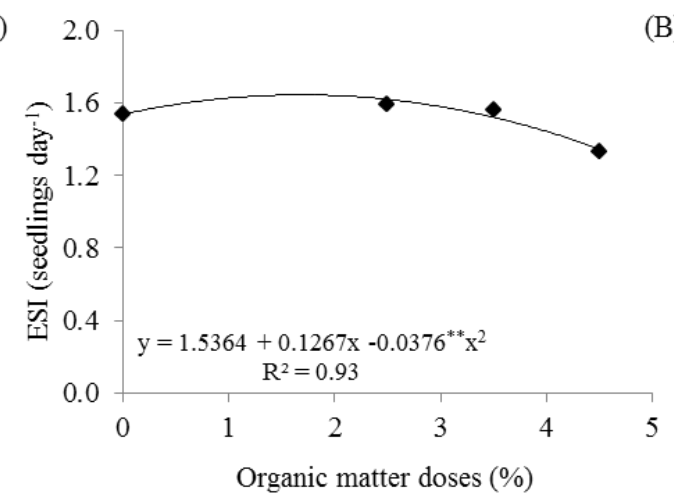

Figure 1. Emergence speed index - ESI of the cotton cv. BRS Jady, as a function of irrigation water electrical conductivity - ECw (A) and organic matter doses (B). 
The increase in irrigation water salinity caused a reduction in stem diameter at 40 DAS (Figure 2A), equal to $1.68 \%$ per unit increase in $\mathrm{ECw}$; i.e., plants irrigated with an ECw of $6.8 \mathrm{dS} \mathrm{m}^{-1}$ showed reductions of $8.58 \% \quad(0.38 \mathrm{~mm})$ in comparison to those irrigated with $1.7 \mathrm{dS} \mathrm{m} \mathrm{m}^{-1}$. Hence, the reduction in stem diameter observed in plants grown under high water salinity conditions possibly results from the decrease in the soil solution osmotic potential, which impedes water absorption by the roots, causing the plant to reduce stomatal opening as a first mechanism to reduce water loss, directly affecting water and nutrient absorption, cell division and elongation, and inhibiting plant growth. Santos et al. (2016), studying the impacts of different levels of irrigation water salinity $\left(0.7\right.$ to $\left.8.7 \mathrm{dS} \mathrm{m}^{-1}\right)$ on the colored cotton BRS Topázio, also observed significant effects of $\mathrm{ECW}$ on stem diameter, with reductions of 0.32 and $0.71 \mathrm{~mm}$ per unit increase in $\mathrm{ECw}$ at 70 and 90 days after sowing.
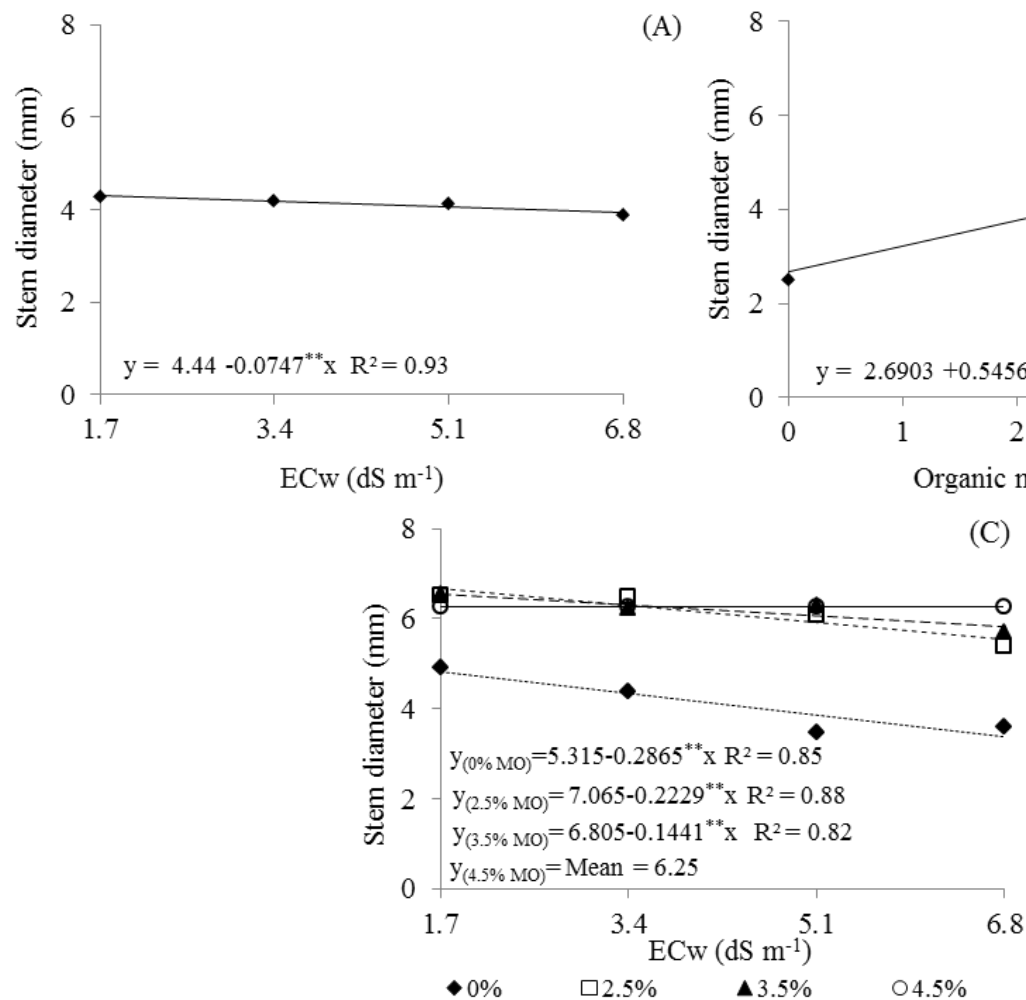

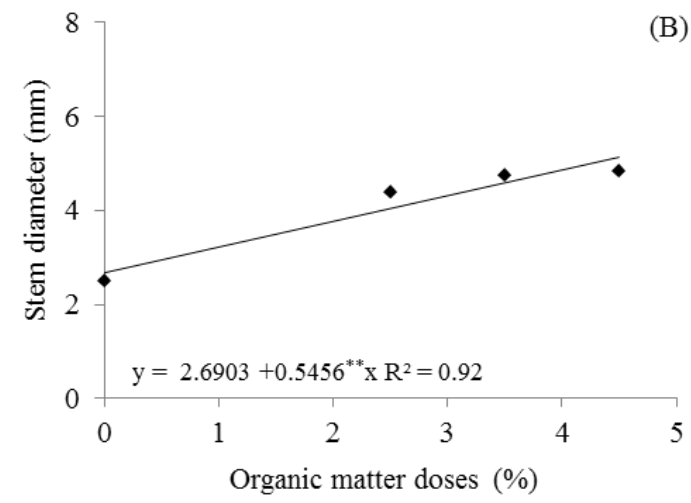

(C)
B) 
increase in ECw; i.e., reductions of $7.01 \mathrm{~cm}$ $(18.07 \%)$ and $15.09 \mathrm{~cm}(24.74 \%)$ in the $\mathrm{PH}$ of cotton plants subjected to the highest salinity level $\left(6.8 \mathrm{dS} \mathrm{m}^{-1}\right)$ in comparison to those irrigated with $1.7 \mathrm{dS} \mathrm{m}^{-1}$ water, respectively. According to the results for SD (Figure 2A), as the evaluation period increased, the effects of salt stress were intensified. Hence, the reduction in $\mathrm{PH}$ due to the $\mathrm{ECW}$ levels must be associated with the increase in soil solution salt concentration, which causes a reduction in the osmotic potential and leads to a higher water retention capacity in the soil, affecting water absorption and decreasing the growth of cultivated

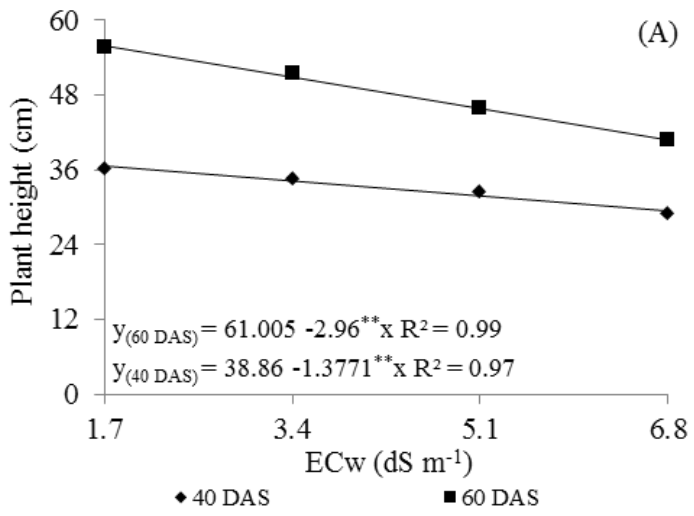

plants (GARCIA et al., 2010). In addition, for the maintenance of osmotic and ionic homeostasis, plants allocate a certain amount of energy to the accumulation of sugars, organic acids, and ions in the vacuole, energy that could be used for growth (SANTOS et al., 2012). Higbie et al. (2010), working with a variety of cotton cultivars (DP 33B, SG 747, Acala Phy 72, Acala 1517-88, JinR 422, and Pima57-4) irrigated with two levels of water salinity $\left(0.57\right.$ and $\left.20 \mathrm{dS} \mathrm{m}^{-1}\right)$, observed that the height of the cultivars was inhibited when plants were irrigated with an ECw of $20 \mathrm{dS} \mathrm{m}^{-1}$.

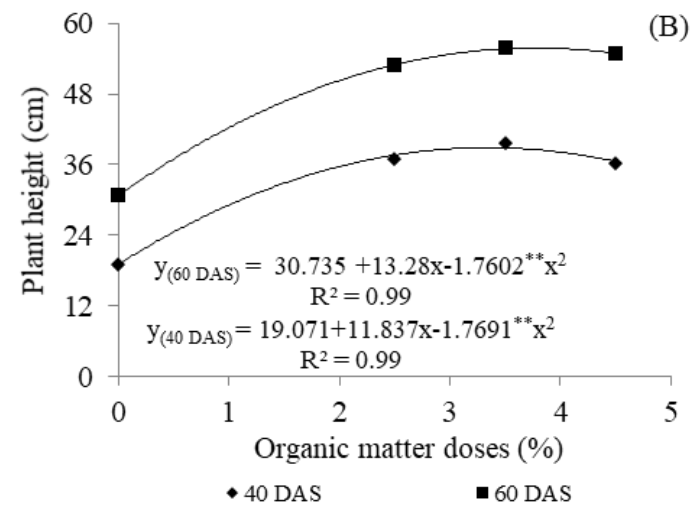

Figure 3. Plant height of the cotton cv. BRS Jady, as a function of irrigation water salinity - ECw (A) and organic matter doses (B), at 40 and 60 days after sowing (DAS).

The organic matter doses had a quadratic effect on plant height at 40 and 60 DAS (Figure 3B) and, according to the regression equations, maximum height values of 38.86 and $55.78 \mathrm{~cm}$ were obtained in plants subjected to doses of 3.3 and $3.8 \%$, respectively. Dias et al. (2016), working with four levels of organic matter (from 0 to $15 \%$ ) in BRS Topázio cotton, observed increments of 25.86 and $23.70 \%$ in height when the plants were subjected to the level of $15 \%$ organic matter, in comparison to plants that did not receive $\mathrm{OM}$ at 55 and 75 DAS, respectively.

Increasing irrigation water salinity also significantly reduced leaf area (LA) in BRS Jady cotton at 40 and 60 DAS (Figure 4A), with reductions of 6.40 and $8.28 \%$ per unit increase in $\mathrm{ECw}$, which correspond to decreases of 166.46 and $537.27 \mathrm{~cm}^{2}$ in LA between plants subjected to $1.7 \mathrm{dS} \mathrm{m}^{-1}$ irrigation water salinity and those at the highest salinity level $\left(6.8 \mathrm{dS} \mathrm{m}^{-1}\right)$. The reduction in leaf area, i.e., in the photosynthetic apparatus, contributes to a decrease in the production of organic photoassimilates and results in plant growth inhibition (SANTOS et al., 2013). In addition, such decrease in leaf area probably results from the reduction in cell volume; a reduction in the transpiring surface leads to the minimization of water loss through stomatal flow, thus contributing to the maintenance of a high water potential in the plant (NASCIMENTO et al., 2011). In a study with the cotton cultivar BRS Topázio, Santos et al. (2016) also found that saline water irrigation ( $\mathrm{ECW}$ values from 0.7 to $8.7 \mathrm{dS} \mathrm{m}^{-1}$ ) led to a reduction in leaf area equal to $5,024.72 \mathrm{~cm}^{2}(67.11 \%)$ in plants under an $\mathrm{ECW}$ of $8.7 \mathrm{dS} \mathrm{m}^{-1}$ in comparison to those under an ECw of $0.7 \mathrm{dS} \mathrm{m}^{-1}$.

Increasing doses of organic matter had positive and significant effects $(p<0.01)$ on leaf area at 40 and 60 DAS (Figure 4B), causing increments of 69.77 and $49.72 \%$ in LA per unit increase in $\mathrm{OM}$ doses, respectively, at 40 and 60 DAS; i.e., plants subjected to an OM dose of $4.5 \%$ showed increments of 524.75 and $1,150.10 \mathrm{~cm}^{2}$ at 40 and $60 \mathrm{DAS}$, in comparison to those that did not receive OM. Hence, increasing doses of organic matter, applied as basal fertilization, possibly promoted the proliferation of microorganisms contained in the organic material added to the soil, which may increase the level of nutrient availability to plants, leading to a greater leaf area in the cotton cv. BRS Jady (RAJENDRAN; DEVARA, 2004). 

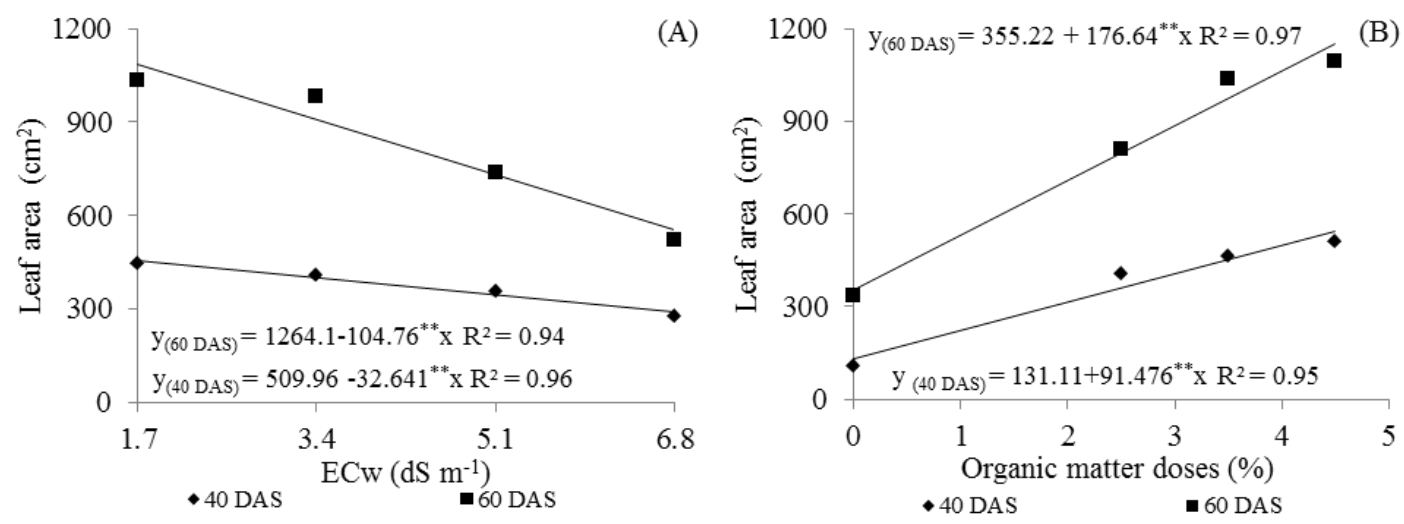

Figure 4. Leaf area of the cotton cv. BRS Jady, as a function of irrigation water salinity - ECw (A) and organic matter doses (B), at 40 and 60 days after sowing (DAS).

Based on the summary of analysis of variance (Table 3), irrigation water salinity and organic matter doses had significant effects on flower abortion rate and seed cotton weight in the cultivar BRS Jady. For the number of days to flower bud opening, only the organic matter doses had significant effects. The interaction between factors (irrigation water salinity and organic matter doses) had a significant effect on the total number of bolls (Table 3 ).

Table 3. Analysis of variance summary for the number of days to flower bud opening (NDFBO) and flower abortion rate (FAR) at 80 days after sowing (DAS), total number of bolls per plant (TNB) and seed cotton weight (SCW) at 114 DAS, in the cotton cv. BRS Jady irrigated with saline water and under different doses of organic matter.

\begin{tabular}{lcccrr}
\hline \multirow{2}{*}{ Source of variation } & \multirow{2}{*}{ DF } & \multicolumn{4}{c}{ Mean squares } \\
\cline { 3 - 6 } & & NDFBO & FAR & TNB & \multicolumn{1}{c}{ SCW } \\
\hline Saline levels (SL) & 3 & $27.74^{\text {ns }}$ & $11.55^{*}$ & $57.36^{* *}$ & $1625.49^{* *}$ \\
Linear regression & 1 & $53.20^{\text {ns }}$ & $1.06^{\text {ns }}$ & $160.06^{* *}$ & $4653.26^{* *}$ \\
Quadratic regression & 1 & $28.52^{\text {ns }}$ & $33.33^{* *}$ & $12.00^{* *}$ & $213.44^{* *}$ \\
Organic matter (OM) & 3 & $300.74^{* *}$ & $107.88^{* *}$ & $47.47^{* *}$ & $1553.22^{* *}$ \\
Linear regression & 1 & $573.50^{* *}$ & $248.06^{* *}$ & $123.26^{* *}$ & $4453.95^{* *}$ \\
Quadratic regression & 1 & $315.18^{* *}$ & $75.01^{* *}$ & $2.08^{* *}$ & $205.01^{* *}$ \\
Interaction (SL x OM) & 9 & $13.90^{\text {ns }}$ & $3.55^{\text {ns }}$ & $2.82^{* *}$ & $43.86^{\text {ns }}$ \\
Blocks & 2 & $73.39^{\text {ns }}$ & $31.08^{*}$ & 1.31 & $5.69^{\text {ns }}$ \\
Residual & & 11.23 & 29.50 & 11.26 & 19.11 \\
\hline
\end{tabular}

$\mathrm{ns}, * *$ * *espectively, not significant, significant at $\mathrm{p}<0.01$ and $\mathrm{p}<0.05$

For the number of days to flower bud opening as a function of organic matter doses in the soil (Figure 5), with increasing OM doses, NDFBO decreased, with a maximum value (51 days) at an OM dose of $0 \%$; however, the lowest value (42 days) was obtained at the $\mathrm{OM}$ dose of $3.3 \%$. The early crop cycle observed in the present study can therefore be considered as an important characteristic, since the Brazilian programs of genetic improvement seek to select increasingly precocious cotton genotypes, aiming at maximum yields within shorter cultivation periods (LIMA et al., 2017). Likewise, Araújo et al. (2001), evaluating the application of increasing doses of organic matter in the form of pig manure in the snap bean crop, also found an advance in the flowering stage, resulting in earlier harvest.
For the flower abortion rate (FAR), the regression equation (Figure 6A) indicates that BRS Jady cotton plants subjected to saline stress in the flowering stage (80 DAS) exhibited an increase in FAR up to the ECw level of $4.1 \mathrm{dS} \mathrm{m}^{-1}(7.62 \%)$, decreasing from this point on to the lowest value (5.54\%), obtained in plants grown under the highest ECw value $\left(6.8 \mathrm{dS} \mathrm{m}^{-1}\right)$. Torabi et al. (2013) reported that, among the deleterious effects of salinity, the reduction in plant fecundity stands out, which leads to higher flower abortion rates, followed by alterations in metabolic reactions in order to attenuate the damages caused by salt stress. Furtado et al. (2014), in a study carried out with a cowpea crop under saline conditions $(\mathrm{ECW}=0.9$ to $4.5 \mathrm{dS} \mathrm{m}^{-1}$ ), also observed that increasing water salinity caused a proportional increment in flower abortion rate. 


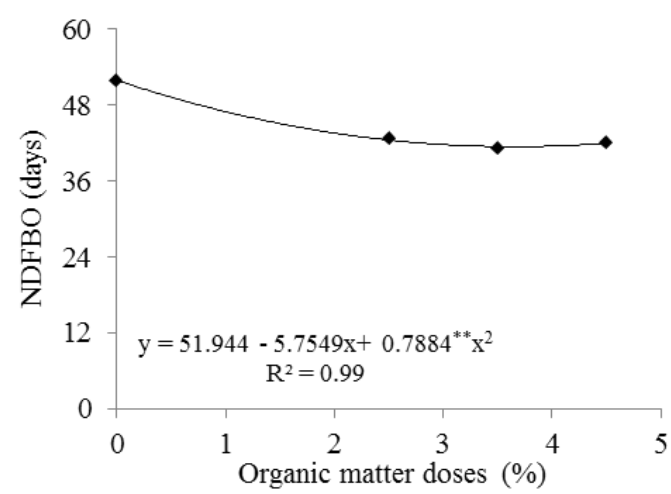

Figure 5. Number of days to flower bud opening (NDFBO) in the cotton cv. BRS Jady, as a function of organic matter doses at 80 days after sowing (DAS).
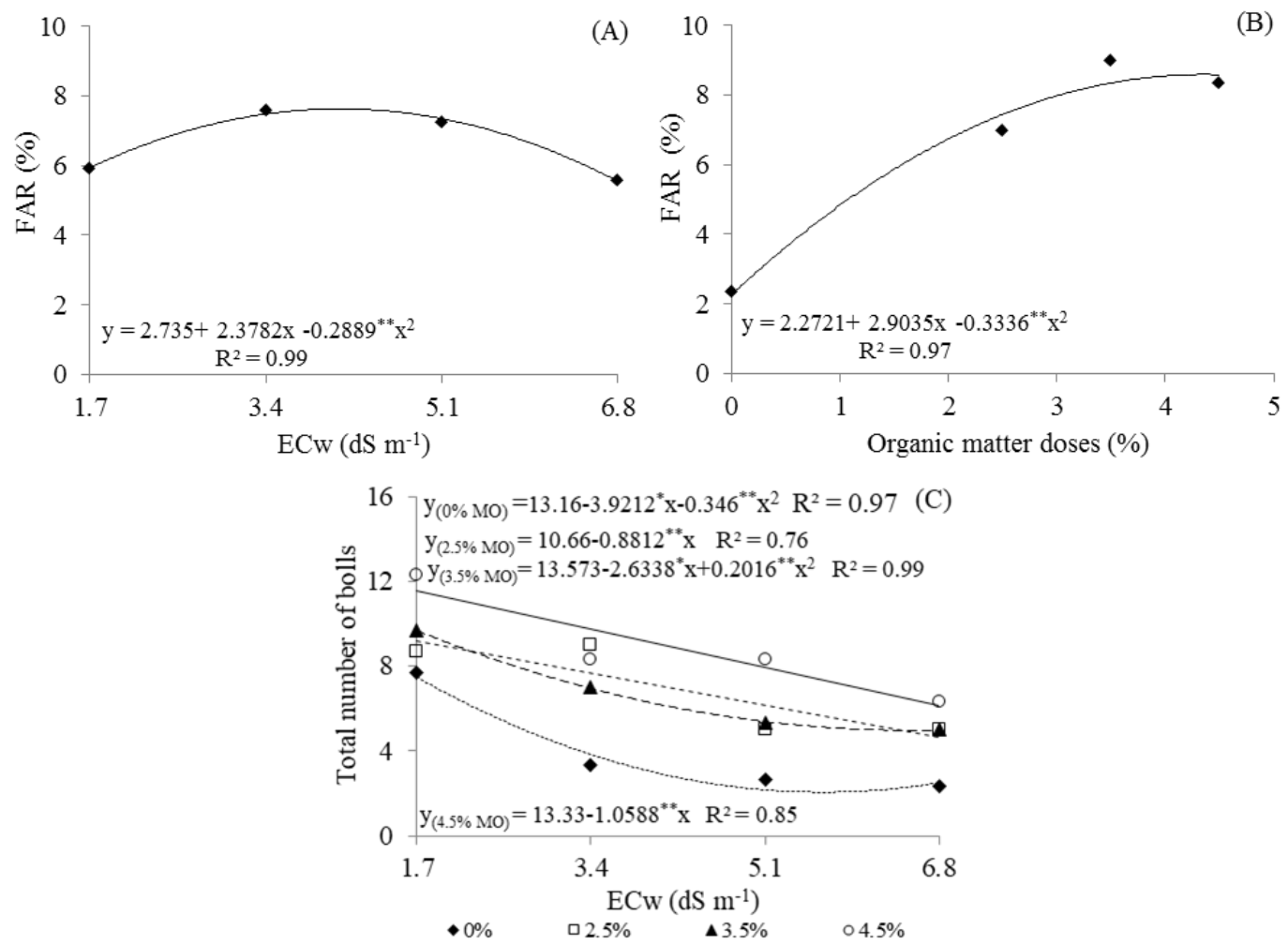

Figure 6. Flower abortion rate - FAR in the cotton cv. BRS Jady, as a function of irrigation water salinity - ECw (A) and organic matter doses (B), and total number of bolls - TNB (C), as a function of the interaction between the factors $\mathrm{ECw}$ levels and organic matter doses, at 80 days after sowing (DAS).

Increasing organic matter doses had a quadratic effect on FAR at $80 \mathrm{DAS}$ and, according to the regression equation (Figure 6B), its maximum value $(8.58 \%)$ was obtained in plants subjected to an OM dose of $4.4 \%$. According to Silva et al. (2011), leaves and reproductive structures compete among themselves for assimilates, especially when plants are still in the growth stage, possibly because OM promotes favorable conditions for an equilibrated balance between vegetative and reproductive growth in cotton plants.

According to the regression equations presented in Figure 6C, the total number of bolls (TNB) exhibited a quadratic response in plants fertilized with $\mathrm{OM}$ doses of 0 and $3.5 \%$, and maximum TNB values of 7.49 and 9.67 bolls plant $^{-1}$ were obtained under irrigation with $1.7 \mathrm{dS} \mathrm{m}^{-1}$ water. In addition, $\mathrm{OM}$ doses of 2.5 and $4.5 \%$ led to linear reductions of 49.05 and $46.83 \%$ in the TNB of plants irrigated with an ECw of $6.8 \mathrm{dS} \mathrm{m}^{-1}$ in comparison to the $\mathrm{ECw}$ of $1.7 \mathrm{dS} \mathrm{m}^{-1}$. However, increasing organic matter doses, even under irrigation with the highest salinity level $\left(6.8 \mathrm{dS} \mathrm{m}^{-1}\right)$, resulted in increases of $2.17,2.49$, and 3.66 bolls in the TNB at OM doses of $2.5,3.5$, and $4.5 \%$, respectively, in comparison to plants without organic fertilization. Although the increase in flower abortion rate occurred due to the different doses of organic matter, it did not reflect in the total number of bolls. Thus, these levels of organic fertilization may have been sufficient to 
nourish the plant with the necessary nutrients. Probably, during plant growth and development, the supplied doses of organic matter, along with the nutrients contained in the soil, has efficiently met the nutritional requirements of the crop, mitigating the deleterious effects of irrigation water salinity and leading to gains in crop production (CAVALCANTE et al., 2010; SILVA et al., 2012).

Seed cotton weight data (Figure 7A) fitted to a quadratic model, and the maximum SCW (43.29 g) was obtained in plants under an ECw of $1.7 \mathrm{dS} \mathrm{m}^{-1}$. In addition, increasing water salinity caused a reduction of $61.03 \%$ in this variable up to the highest salinity level $\left(6.8 \mathrm{dS} \mathrm{m}^{-1}\right)$ in comparison to the $\mathrm{ECW}$ of $1.7 \mathrm{dS} \mathrm{m}^{-1}$. The reduction observed in seed cotton weight (Figure 7A) results from the accentuated

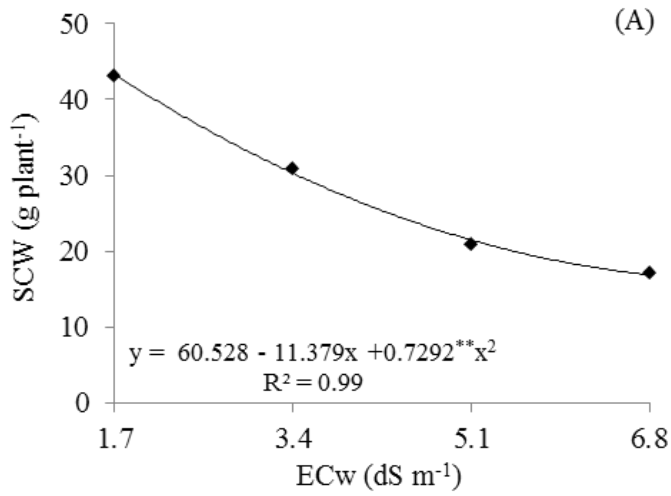

decrease in the growth of cotton plants, evidenced by $\mathrm{SD}, \mathrm{PH}$, and $\mathrm{LA}$, caused by the reduction in the soil solution osmotic potential due to the high saline concentration. This situation imposes a higher expenditure of energy on the plants for water absorption and maintenance of metabolic activity, besides the synthesis of organic solutes for osmoregulation and/or protection of macromolecules. As a consequence, plant growth is reduced, which results in lower production (LEONARDO et al., 2007). Jácome et al. (2003), working with different cotton genotypes under irrigation water salinity levels ranging from 2.0 to $10.0 \mathrm{dS} \mathrm{m} \mathrm{m}^{-1}$, also found losses in the production components in response to water salinity.

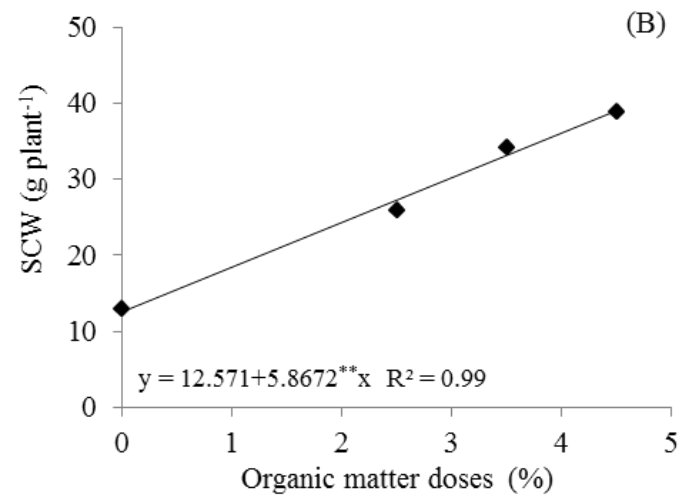

Figure 7. Seed cotton weight - SCW in the cotton cv. BRS Jady, as a function of irrigation water salinity - ECw (A) and organic matter doses (B) at 114 days after sowing (DAS).

Seed cotton weight was significantly and linearly influenced by the fertilization with increasing doses of organic matter, and its highest value $\left(38.97 \mathrm{~g} \mathrm{plant}^{-1}\right)$ was obtained in cotton plants grown at an OM dose of $4.5 \%$ (Figure $7 \mathrm{~B}$ ), which is equivalent to an increment of $26.39 \mathrm{~g}$ compared with plants cultivated with no addition of organic matter. This result reinforces the importance of using organic matter for the growth and production of crops. Similar results were also found by Pereira et al. (2012), who evaluated the effect of six doses of bovine manure $\left(0,2.5,5,10,20\right.$, and $\left.40 \mathrm{Mg} \mathrm{ha}^{-1}\right)$ on agronomic and fiber characteristics of the colored cotton BRS Rubi and also observed that the dose of $28 \mathrm{Mg} \mathrm{ha}^{-1}$ promoted maximum yield, corresponding to $1,111.19 \mathrm{~kg} \mathrm{ha}^{-1}$ of seed cotton.

\section{CONCLUSIONS}

Increasing irrigation water salinity reduces emergence, growth, and production in the colored cotton cv. BRS Jady, and seed cotton weight is the variable most affected by salinity. Organic matter addition promotes increased cotton growth and production, especially in terms of seed cotton weight. Increasing doses of organic matter attenuate the effect of irrigation water salinity on the number of bolls in the cotton cv. BRS Jady.

\section{ACKNOWLEDGMENTS}

To the National Program of Post-Doctorate (PNPD/CAPES/UFCG), for granting the scholarship to the second author and to the National Institute of Science and Technology in Salinity - INCTSal, for funding the project.

\section{REFERENCES}

ABREU, N. A. A. et al. Crescimento de mudas de pitangueira (Eugenia uniflora L.) em substratos com utilização de superfosfato simples. Ciência e Agrotecnologia, Lavras, v. 29, n. 6, p. 1117-1124, 2005.

ALVES, M. S. et al. Estratégias de uso de água salobra na produção de alface em hidroponia NFT. Revista Brasileira de Engenharia Agrícola e Ambiental, Campina Grande, v. 15, n. 5, p. 491498, 2011. 
ARAÚJO, J. S. et al. Rendimento do feijão-vagem cultivado com esterco suíno e adubação mineral. Revista Ceres, Viçosa, v. 48, n. 278, p. 501-510, 2001.

AREF, F.; RAD, H. E. Physiological characterization of rice under salinity stress during vegetative and reproductive stages. Indian Journal of Science and Technology, Jaipur, v. 5, n. 4, p. 2578-2586, 2012.

ASIK, B. B. et al. Effects of humic substances on plant growth and mineral nutrients uptake of wheat (Triticum durum cv. Salihli) under conditions of salinity. Asian Journal of Crop Science, Islamabad, v. 1, n. 2, p. 87-95, 2009.

CARDOSO, G. D. et al. Períodos de interferência das plantas daninhas em algodoeiro de fibra colorida BRS Safira. Revista Ciência Agronômica, Fortaleza, v. 41, n. 3, p. 456-462, 2010.

CAVAlCANTE, I. H. L. et al. Fertilizantes orgânicos para o cultivo da melancia em Bom JesusPI. Revista Brasileira de Ciências Agrárias, Recife, v. 5, n. 4, p. 518-524, 2010.

CAVALCANTE, L. F. et al. Crescimento e produção do maracujazeiro amarelo em solo de baixa fertilidade tratado com biofertilizantes líquidos. Revista Brasileira de Ciências Agrárias, Recife, v. 2, n. 1, p. 15-19, 2007

CAVALCANTE, L. F. et al. Estado nutricional de pinheira sob adubação orgânica do solo. Revista Ciência Agronômica, Fortaleza, v. 43, n. 3, p. 579$588,2012$.

CLEMENTE, R. et al. The use of a halophytic plant species and organic amendments for the remediation of a trace elements contaminated soil under semiarid conditions. Journal of Hazardous Materials, Amsterdam, v. 223-224, n. 1, p. 63-71, 2012.

DAMATTO JÚNIOR, E. R.; LEONEL, S.; PEDROSO, C. J. Adubação orgânica na produção e qualidade de frutos de maracujá-doce. Revista Brasileira de Fruticultura, Jaboticabal, v. 27, n. 1, p. 188-190, 2005.

DANIEL, V. C. et al. Germinação e crescimento de plântulas de algodão colorido sob condições de estresse salino. Revista em Agronegócios e Meio Ambiente, Maringá, v. 4, n. 2, p. 321-333, 2011.

DIAS, A. S. et al. Crescimento e produção de algodoeiro de fibra colorida cultivado em solo salino -sódico e adubação orgânica. Irriga, Botucatu, Sup., p. $260-273,2016$
FERREIRA, D. F. Sisvar: A computer statistical analysis system. Revista Ciência e Agrotecnologia, Lavras, v. 35, n. 6, p. 1039-1042, 2011.

FURTADO, G. F. et al. Pigmentos fotossintéticos e produção de feijão Vigna unguiculata L. Walp. sob salinidade e adubação nitrogenada. Revista Verde de Agroecologia e Desenvolvimento Sustentável, Mossoró, v. 9, n. 2, p. 291-299, 2014.

GARCIA, G. O. et al. Respostas de genótipos de feijoeiro à salinidade. Engenharia na Agricultura, Viçosa, v. 18, n. 4, p. 330-338, 2010.

GRIMES, D. W.; CARTER, L. M. A linear rule for direct non destructive leaf área measurements. Agronomy Journal, Madison, v. 61, n. 3, p. 477 $479,1969$.

HIGBIE, S. M. et al. Physiological response to salt $(\mathrm{NaCl})$ stress in selected cultivated tetraploid cottons. International Journal of Agronomy, New York, v. 2010, n. 1, p. 1-12, 2010.

JÁCOME, A. G. et al. Comportamento produtivo de genótipos de algodão sob condições salinas. Acta Scientiarum Agronomy, Maringá, v. 25, n. 1, p. 187-194. 2003.

JIANG, J. et al. Effect of irrigation amount and water salinity on water consumption and water productivity of spring wheat in Northwest China. Field Crops Research, Amsterdam, v. 137, n. 1, p. 78-88, 2012.

LEONARDO, M. et al. Produção de frutos de pimentão em diferentes condições salinas. Irriga, Botucatu, v. 12, n. 1, p. 73-82, 2007.

LIMA, G. S. et al. Cultivation of CNPA G3 sesame irrigated with saline water and fertilized with nitrate$\mathrm{N}$ and ammonium-N. Revista Brasileira de Engenharia Agrícola e Ambiental, Campina Grande, v. 21, n. 1, p. 14-20, 2017.

LOPES, K. P.; SILVA, M. Salinidade na germinação de sementes de algodão colorido. Revista Verde de Agroecologia e Desenvolvimento Sustentável, Mossoró, v. 5, n. 3, p. 274-279, 2010.

MAHMOUD, A. A.; MOHAMED, H. F. Impact of biofertilizers application on improving wheat (Triticuma estivum L.) resistance to salinity. Research Journal of Agriculture and Biological Sciences, Amman, v. 4, n. 5, p. 520-528, 2008.

MELO FILHO, J. S. et al. Resposta de duas variedades de caju (Anacardium occidentale L.) à fertilização orgânica. NUPEAT-IESA-UFG, Goiânia, v. 5, n. 2, p. 285-294, 2015. 
MESQUITA, E. F. et al. Produção de mudas de mamoneira em função de substratos contendo esterco bovino e volumes de recipientes. Revista Brasileira de Ciências Agrárias, Recife, v. 7, n. 1, p. 58-65, 2012.

MGUIS, K. et al. Adjustments in leaf water relations of wild wheat relative Aegilops geniculata Roth. and wheat (Triticum durum Desf.) plants grown in a salinity gradient. Australian Journal of Crop Science, Queensland, v. 6, n. 5, p. 768-776, 2012.

NASCIMENTO, J. A. M. et al. Efeito da utilização de biofertilizante bovino na produção de mudas de pimentão irrigadas com água salina. Revista Brasileira de Ciências Agrárias, Recife, v. 6, n. 2, p. 258-264, 2011.

NEVES, A. L. R. et al. Acumulação de biomassa e extração de nutrientes por plantas de feijão-de-corda irrigado com água salina em diferentes estádios de desenvolvimento. Ciência Rural, Santa Maria, v. 39, n. 3, p. 758-765, 2009.

NOVAIS, R. F.; NEVES, J. C. L.; BARROS, N. F. Ensaio em ambiente controlado. In: OLIVEIRA, A. J. et al. (Eds.). Métodos de pesquisa em fertilidade do solo. Brasília: Embrapa SEA, 1991. p. 189-253.

OLIVEIRA, F. T. et al. Produção de mudas de goiabeira com diferentes fontes e proporções de adubos orgânicos. Revista Verde de Agroecologia e Desenvolvimento Sustentável, Mossoró, v. 9, n. 2, p. 111-116, 2014.

PEREIRA, J. R. et al. Doses de esterco bovino nas características agronômicas e de fibras do algodoeiro herbáceo BRS Rubi. Revista Agro@mbiente, Boa Vista, v. 6, n. 3, p. 195-204, 2012.

RAJENDRAN, K.; DEVARA, J, P. Biomass and nutrient distribution and their return of Casuarina equisetifolia inoculated with biofertilizers in farm land. Biomass and Bioenergy, Amsterdam, v. 26, n. 3, p. 235-249, 2004.

RIBEIRO, S. A. et al. Aplicação de fontes orgânicas e mineral no desenvolvimento e produção do melão no sul do Estado do Piauí. Revista Verde de Agroecologia e Desenvolvimento Sustentável, Mossoró, v. 9, n. 1, p. 320-325, 2014.

RICHARDS, L. A. Diagnosis and improvement of saline and alkali soils. 1. ed. Washington: U. S. Department of Agriculture, 1954. 160 p. (Agriculture Handbook, 60).

SÁ, F. V. S. et al. Influência do gesso e biofertilizante nos atributos químicos de um solo salino-sódico e no crescimento inicial do girassol. Irriga, Botucatu, v. 20, n. 1, p. 46-59, 2015.

SANTOS, B. et al. Produção e parâmetros fisiológicos do amendoim em função do estresse salino. Idesia, Arica, v. 30, n. 2, p. 69-74, 2012.

SANTOS, J. B. et al. Comportamento morfofisiológico da mamoneira BRS Energia submetida à irrigação com água salina. Revista Brasileira de Engenharia Agrícola e Ambiental, Campina Grande, v. 17, n. 2, p. 145-152, 2013.

SANTOS, J. B. et al. Morfofísiologia e produção do algodoeiro herbáceo irrigado com águas salinas e adubado com nitrogênio. Comunicata Scientiae, Bom Jesus, v. 7, n. 1, p. 86-96, 2016.

SILVA, A. G. et al. Produção do algodão colorido cv. BRS Topázio submetido a diferentes coberturas no solo. In: VI CONGRESSO BRASILEIRO DE MAMONA, III SIMPÓSIO INTERNACIONAL DE OLEAGINOSAS ENERGÉTICAS, 6, 2014, Fortaleza. Anais... Fortaleza: Embrapa Algodão, 2014. p. 67.

SILVA, I. P. F. et al. Estudo das fases fenológicas do algodão (Gossypium hirsutum L.). Revista Científica Eletrônica de Agronomia, Garça, v. 10, n. 20, p. 1-10, 2011.

SILVA, J. A. et al. Rendimento do inhame adubado com esterco bovino e biofertilizante no solo e na folha. Revista Brasileira de Engenharia Agrícola e Ambiental, Campina Grande, v. 16, n. 3, p. 253 257,2012 .

TORABI, F. et al. Effects of salinity on the development of hydroponically grown borage (Borago officinalis L.) male gametophyte. Notulae Botanicae Horti Agrobotanici, Cluj-Napoca, v. 41, n. 1, p. 65-72, 2013.

VIEIRA, R. D.; CARVALHO, N. M. Testes de vigor em sementes. 1. ed. Jaboticabal, SP: FUNEP, 1994. 164 p.

VOIGT, E. L. et al. Source-sink regulation of cotyledonary reserve mobilization during cashew (Anacardium occidentale) seedling establishment under $\mathrm{NaCl}$ salinity. Journal of Plant Physiology, Stuttgart, v. 166, n. 1, p. 80-89, 2009. 